\title{
PENGARUH SUBSTITUSI BONGGOL PISANG (Musa paradisiaca) DAN PERENDAMAN KITOSAN TERHADAP KANDUNGAN GIZI DAN MUTU TEMPE
}

\author{
(The Effect of Banana Weevil Substitute and Chitosan Dipping in Nutrition \\ Component and the Quality of Tempeh)
}

\author{
Purwaningtyas Kusumaningsih ${ }^{a^{*}}$, I Gede Mustika ${ }^{a}$ \\ ${ }^{a}$ Fakultas Kesehatan, Sains dan Teknologi, Universitas Dhyana Pura, Bali, Indonesia \\ *Penulis korespondensi: \\ Email: purwak.05@undhirabali.ac.id
}

\begin{abstract}
The present study was to evaluate nutrition of tempeh made from banana tuber as soybean substitute. The soy beans and banana tuber were soaked in $2 \%$ of chitosan as preservative before being mixed. Three formulations of soybean and banana tuber mixture: $70 \%+30 \%$ (TB1); $60 \%+40 \%$ (TB2) and $50 \%+50 \%$ (TB3), were established. For each formulations, these parameters were evaluated: water content, ash, protein, fat, carbohydrate, fiber and $\mathrm{pH}$. The result from the three formulas analysis will be compared with the control (100\% soybeans). The water content from three formulas were below Indonesia's National Standard for tempeh (3144:2015), it was more than 65\%. The substitution soybean with banana weevil did not influence ash content compared with the control. Otherwise, the protein decreased in the three formulas. The lowest percentage of fat was shown in TB3. The best carbohydrate result was obtained in TB3. The highest percentage of fiber was obtained in TB3. The $\mathrm{pH}$ decreased in the three formulas. From the Least Significant Difference (LSD) analysis, substitute of soybeans with banana tuber and $2 \%$ chitosan treatment influenced the water content, protein, fat, fiber and $\mathrm{pH}$.
\end{abstract}

Keywords: banana weevil, chitosan, proximate analysis, tempeh

\begin{abstract}
ABSTRAK
Penelitian ini dilakukan untuk menganalisis kandungan gizi tempe yang dibuat dari campuran kedelai dan bonggol pisang sebagai substitusi kedelai. Sebelumnya kedelai dan bonggol pisang direndam dalam larutan kitosan $2 \%$ sebagai pengawet. Terdapat tiga formula tempe campuran perbandingan kedelai dan bonggol: $70 \%+30 \%$ (TB1); $60 \%+40 \%$ (TB2) dan $50 \%+50 \%$ (TB3) yang dianalisis kandungan air, abu, protein, lemak, karbohidrat, serat kasar dan $\mathrm{pH}$. Hasil analisis dari ketiga formula dibandingkan dengan tempe kedelai sebagai kontrol. Kadar air ketiga formula tempe bonggol belum sesuai dengan standar SNI 3144:2015 yaitu diatas 65\%. Substitusi kedelai dengan bonggol tidak mempengaruhi kadar abu tempe, tetapi mempengaruhi kadar protein semakin menurun di TB3. Kadar lemak terbaik dihasilkan oleh TB3. Kandungan karbohidrat formula TB3 sama baiknya dengan kontrol (100\% kedelai). Kandungan serat kasar terbaik ditunjukkan oleh TB3. Kisaran $\mathrm{pH}$ semakin asam pada ketiga formula. Pada analisis Least Significant Difference (LSD) substitusi kedelai dengan bonggol pisang dan perendaman dalam larutan $2 \%$ kitosan menunjukkan pengaruh terhadap kadar air, protein, lemak, serat kasar dan perubahan pH.
\end{abstract}

Kata kunci: bonggol pisang, uji proksimat, kitosan, tempe 


\section{PENDAHULUAN}

Ketahanan pangan dalam suatu negara memiliki peranan penting dalam pemenuhan kebutuhan pangan bagi setiap individu sebagai bagian dari hak asasi manusia. Kebutuhan pangan, diperlukan untuk menunjang pembangunan bangsa khususnya membentuk sumber daya manusia yang bekualitas. Ketersediaan pangan yang aman dikonsumsi dengan harga terjangkau oleh seluruh lapisan masyarakat diharapkan mampu menjawab permasalahan gizi. Pangan memiliki cakupan yang luas, mencakup tanaman pangan, ternak dan ikan untuk memenuhi sumber karbohidrat, protein, lemak, vitamin dan mineral yang bermanfaat dalam meningkatkan status gizi masyarakat (Isbandi dan Rusdiana, 2014; Lestari et al., 2018).

Indonesia dikenal sebagai negara agraris, memiliki lahan yang luas dan subur. Salah satunya adalah tanaman pisang, Indonesia memiliki lebih dari 200 jenis pisang dan sangat mudah ditemukan di seluruh wilayah Indonesia. Keunggulan dari tanaman pisang ini, hampir semua bagian dapat digunakan sebagai bahan pangan (Suharyanto, 2011).

Diversifikasi produk dari tanaman pisang telah banyak dikembangkan, mulai dari buah hingga bonggol pisang. Jantung pisang telah dikembangkan sebagai campuran abon ikan yang diketahui mampu meningkatkan kandungan serat abon ikan (Jumiati dan Fitriana, 2018). Bonggol pisang berdasarkan penelitian memiliki kadungan karbohidrat cukup tinggi yaitu $15 \mathrm{mg} / 100 \mathrm{gr}$ pada bonggol basah dan $60 \mathrm{mg} / 100 \mathrm{gr}$ pada bonggol kering. Kandungan karbohidrat tersebut menunjukkan bonggol pisang memiliki kadar serat cukup tinggi (Rohmani dan Adi, 2019).

Pemanfaatan bonggol pisang sebagai produk diversifikasi pangan memberikan peluang baik untuk pengembangan pariwisata kuliner sekaligus memanfaatkan bahan pangan lokal (Saragih dan Katarida, 2018). Diversifikasi bonggol pisang dijadikan sebagai campuran bahan olahan tempe sebagai bahan substitusi kedelai. Tempe merupakan makanan khas asli Indonesia. Beragam jenis tempe ditemukan di berbagai daerah di Indonesia seperti tempe benguk, gembus, bongkrek, koro, gude, jagung, lamtoro gung dan kacang merah (Lestari dan Eva, 2016; Muthmainna et al., 2016; Sine dan Endang, 2016). Beberapa penelitian fortifikasi bahan tambahan tempe sudah dilakukan oleh beberapa peneliti. Penambahan biji nangka, bekatul, kitosan, probiotik, zat besi dan vitamin A dilakukan untuk meningkatkan kandungan gizi tempe (Astuti et al., 2014; Harti et al., 2014; Sari et al., 2016). Impor kedelai ke Indonesia dalam memenuhi kebutuhan usaha tempe masih tinggi, sehingga perlu dicari alternatif bahan baku tambahan pembuatan tempe. Hasil penelitian Dewayani dan Andi (2016), varietas kedelai lokal memiliki keunggulan lebih baik dari segi kadar kabohidrat dan lemak lebih rendah yaitu $3,23 \%$ dan $10,67 \%$ sedangkan kedelai impor USA memiliki kadar sebesar 4,03\% dan 13,61\%. Kadar serat kasar keduanya sama-sama rendah sekitar $2 \%$, begitu pula dengan protein keduanya hampir sama sekitar $20 \%$.

Nilai gizi ditentukan pula dari kualitas bahan baku yang bebas dari pencemaran bakteri. Kerusakan kandungan gizi setelah melalui proses pengolahan sebisa mungkin diminimalkan. Penggunaan edible coating kitosan pada pengolahan tahu, diketahui dapat meningkatkan kadar protein karena kemampuan kitosan dalam mengikat air (Vega et al., 2013). Morachis-valdez et al., (2017), menemukan kemampuan edible coating kitosan dapat mempertahankan kandungan asam amino filet ikan mas dengan mengurangi terjadinya proses oksidasi protein.

Masa depan suatu bangsa ditentukan oleh terjaminnya kesehatan generasi penerus. Kesehatan penting didukung dengan pemenuhan pangan yang bergizi, mudah diperoleh, terjangkau serta bebas penyakit. Nutrisi utama yang diperlukan seperti karbohidrat, protein dan lemak sebagai penunjang energi tubuh, pertumbuhan fisik dan mental (Schmidhuber et al., 2018). Kandungan serat pada makanan diperlukan untuk mengatasi 
obesitas pada remaja. Makanan berserat lebih cepat mengenyangkan serta mengurangi kelebihan glukagon yang disimpan pada sel adiposa (Ruhee dan Katsuhiko, 2018).

Berdasarkan penelitian terdahulu, pada penelitian ini bonggol pisang ditambahkan sebagai bahan substitusi kedelai lokal pada tempe bertujuan untuk mengetahui apakah penambahan bonggol pisang sebagai bahan substitusi pada tempe, memengaruhi kadar air, $\mathrm{pH}$ dan kandungan gizi proksimat tempe kedelai lokal. Hasil gizi yang diperoleh akan dibandingkan dengan standar SNI 3144:2015 tempe kedelai. Kitosan yang ditambahkan melalui kemampuan edible coating pada kedelai dan bonggol pisang diharapkan mampu memperpanjang daya simpan pada tempe dan dapat dijadikan antimikroba terhadap pencemaran bakteri coliform dan Salmonella sp., yang berasal dari air yang tercemar.

\section{Bahan}

\section{BAHAN DAN METODE}

Bahan yang digunakan dalam penelitian ini adalah kedelai lokal, bonggol pisang, larutan kitosan (BioChitosan), air, ethanol (Sigma-Aldrich), NaNO2 (Sigma-Aldrich), larutan DPPH (2,2-diphenyl-1 picrylhydrazyl) $0,1 \mathrm{mM}$, dan aquadest. Bahan kimia yang digunakan dalam analisis proksimat: $\mathrm{H} 2 \mathrm{SO} 4$ (Sigma-Aldrich), $\mathrm{NaSO} 4, \mathrm{HgO}, \mathrm{H} 3 \mathrm{BO} 3$ (asam borat) (Sigma-Aldrich), aquadest, $\mathrm{NaOH}-\mathrm{Na} 2 \mathrm{~S} 2 \mathrm{O} 3$ (natrium tiosulfat) (SigmaAldrich), indikator pp (indikator fenolftalein), indikator merah metil, metilen blue, $\mathrm{HCl}$ (Sigma-Aldrich), kertas saring, pelarut lemak (hexan), kapas wool.

\section{Preparasi Bahan}

Kedelai lokal sebanyak 600 gram yang telah melalui proses perendaman dalam air selama 6 jam dan direbus selama 30 menit. Kemudian direndam selama 24 jam, keesokan harinya kedelai dicuci, dihilangkan kulit arinya dan direbus kembali selama 30 menit. Terakhir, kedelai dicuci hingga bersih.
Bonggol dari 1 pohon pisang, dibersihkan dan diiris balok kemudian direbus selama 30 menit dan ditiriskan.

Larutan kitosan dibuat menjadi konsentrasi $2 \%$ dari sediaan $50 \%$ per $\mathrm{ml}$. Sebanyak $10 \mathrm{ml}$ cairan kitosan dengan konsentrasi $500 \%$ diencerkan dengan menambahkan air sebanyak $250 \mathrm{ml}$ sehingga konsentrasi menjadi $2 \%$.

\section{Metode pengolahan}

Sebanyak 100 gram kedelai direndam dalam larutan kitosan $2 \%$ selama 3 menit kemudian ditiriskan. Bonggol pisang yang telah direbus, diparut dan ditimbang sebanyak 200 gram kemudian direndam selama 3 menit dalam larutan kitosan $2 \%$.

Kedelai dan bonggol pisang yang telah direndam dalam kitosan dicampur sesuai dengan formulasi TB1 (bonggol 30\%, kedelai $70 \mathrm{gr}$ ); TB2 (bonggol $40 \%$, kedelai $60 \mathrm{gr}$ ) dan TB3 (bonggol 50\%, kedelai $50 \mathrm{gr}$ ) ditambahkan ragi tempe (Sari et al., 2016). Pada penelitian ini menggunakan kedelai lokal $100 \%$ tanpa bonggol sebagai kontrol (TB0).

\section{Metode Analisis Kadar air, Derajat Keasaman, dan Kandungan Gizi,}

Metode yang digunakan dalam menguji parameter kadar air dilakukan dengan Thermogravimetri, kadar abu dan tingkat keasaman dengan metode AOAC (Setyani et al., 2017; Banobe et al., 2019), kadar protein menggunakan metode Lowry (Yazid dan Badilatun, 2017), kadar lemak dilakukan dengan metode soxhlet (Dewi et al., 2014). Kadar karbohidrat dianalisis menggunakan by difference (Dewi et al., 2014) dan kadar serat kasar menggunakan metode perlakuan asam dan basa panas (Widoyo et al., 2015).

\section{Analisis Statistik}

Penelitian ini menggunakan jenis eksperimen dengan desain studi deskriptif. Rancangan penelitian menggunakan Rancangan Acak Lengkap (RAL), terdiri dari 4 sampel yaitu 1 kontrol dan 3 kombinasi. Analisis data terhadap tiga tingkat substitusi bonggol pisakng yaitu $30 \%, 40 \%$ dan $50 \%$, 
dilakukan dengan menggunakan one way ANOVA dan uji lanjut Least Significant Differences (LSD) dengan tingkat kepercayaan $\alpha=0,05$.

HASIL DAN PEMBAHASAN

Tempe dengan substitusi bonggol pisang berproses menjadi tempe bervariasi antara 2 hari hingga setelah didiamkan selama 2 hari semalam. Pada Gambar 1. terlihat bentuk tempe campuran bonggol $30 \%, 40 \%$ dan $50 \%$ secara kasat mata sama dengan tempe kedelai $100 \%$. Substitusi bonggol pisang dapat terbungkus solid dengan kapang dari jamur Rhizopus bersama dengan kedelai. Secara morfologi tempe kedelai bonggol pisang dengan campuran 50\%, terlihat warna kecoklatan pada permukaan lebih dominan dibandingkan dengan campuran $30 \%$ dan $40 \%$.

Pada saat diiris kekompakan nampak berbeda antara perlakuan dengan kontrol. Pada substitusi $30 \%$ bonggol pisang lebih kompak atau padat dibandingkan dengan substitusi $40 \%$ dan 50\%. Sedangkan substitusi $50 \%$ lebih rapuh dan basah dibandingkan kontrol dan perlakuan lainnya (Gambar 2). Tekstur tempe menjadi terlalu empuk disebabkan bonggol pisang mudah untuk menyerap uap air akibat panas yang ditimbulkan selama fermentasi (Kurniawan et al., 2019). Bonggol pisang merupakan bagian dari pisang berfungsi sebagai penyimpan air (Rosariastuti et al., 2018). Kandungan serat berupa selulosa dalam bonggol memiliki kemampuan mengikat air (Supraptiningsih, 2012).

Hasil perendaman kedelai dan bonggol pisang dalam larutan kitosan $2 \%$ dan substitusi 30\%, 40\% dan 50\% kedelai dengan bonggol pisang menunjukkan pengaruh terhadap nilai gizi makro tempe. Hasil uji proksimat dapat dilihat di Tabel 1. berikut ini:

Terlihat pada Tabel 1. diatas, kadar air paling tinggi dtunjukkan pada perlakuan TB2. Kadar protein semakin menurun pada perlakuan TB3, tetapi kandungan serat kasarnya semakin meningkat. Kadar abu dan lemak tidak menunjukkan perubahan nilai terlalu besar. Sedangkan kadar karbohidrat menurun pada perlakuan TB1 dan TB2 tetapi kembali naik pada TB3.

\section{Kadar Air}

Hasil analisis kadar air sampel tempe bonggol kitosan dengan 3 variasi substitusi bonggol dan perendaman $2 \%$ kitosan dapat dilihat pada Gambar 3. Tempe yang disubstitusi dengan bonggol dan perendaman kitosan menunjukkan peningkatan pada kadar air dibandingkan kontrol. Kadar air dari tempe dengan substitusi bonggol, ketiganya belum memenuhi standar SNI 3144:2015 karena melebihi batas maksimal 65\%. Tingginya kadar air dalam sebuah produk makanan memungkinkan terjadinya pertumbuhan mikroba lebih cepat. Pertumbuhan mikroba ini mempengaruhi daya simpan tempe karena cepat membusuk akibat aktivitas metabolisme mikroba (Razie dan Lina, 2018). Hasil analisis Least Significant Difference (LSD) diperoleh hasil $\mathrm{p}<0.05$ antara kontrol dan tempe bonggol kitosan.

Penyebab kadar air yang meningkat dapat dipengaruhi kemasan yang digunakan adalah daun pisang yang juga mengandung kadar air. Pertukaran gas oksigen yang mampu menembus celah pori daun pisang sehingga kelembapan tinggi dan uap air diserap oleh bonggol pisang. Putri et al. (2018) menemukan bahwa tempe yang dibungkus dengan berbagai macam daun memiliki kadar air diatas 60\% jika dibandingkan dengan pengemasan vakum udara atau aluminium foil. Tetapi jika dibandingkan dengan pengemasan plastik, kadar air lebih tinggi akibat terperangkapnya air didalam kemasan plastik dan lebih cepat busuk bila dibandingkan dengan pembungkus plastik (Sulistiyono et al., 2016; Kurniawan et al., 2019).

\section{Kadar Abu}

Pada Gambar 4. dapat dilihat kadar abu tempe menggunakan substitusi bonggol pisang dan perendaman dengan kitosan $2 \%$ berdasarkan analisis LSD tidak 


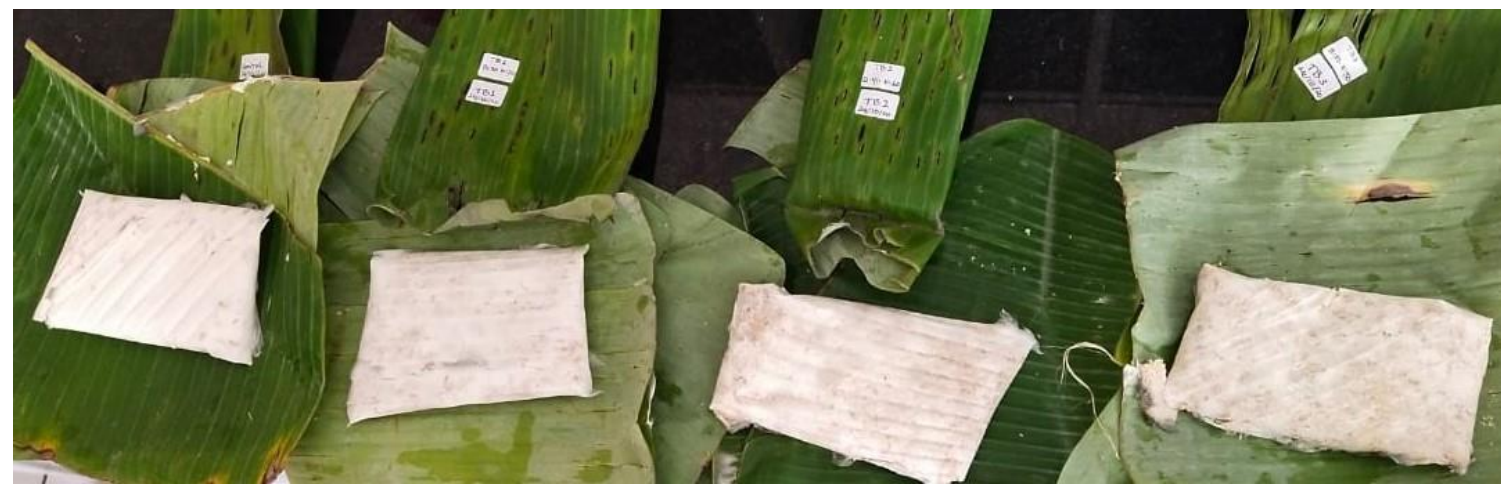

Gambar 1. Penampakan morfologi tempe. Kontrol: 100\% kedelai; TB1: 70\% kedelai; TB2: 60\% kedelai; TB3: $50 \%$ kedelai

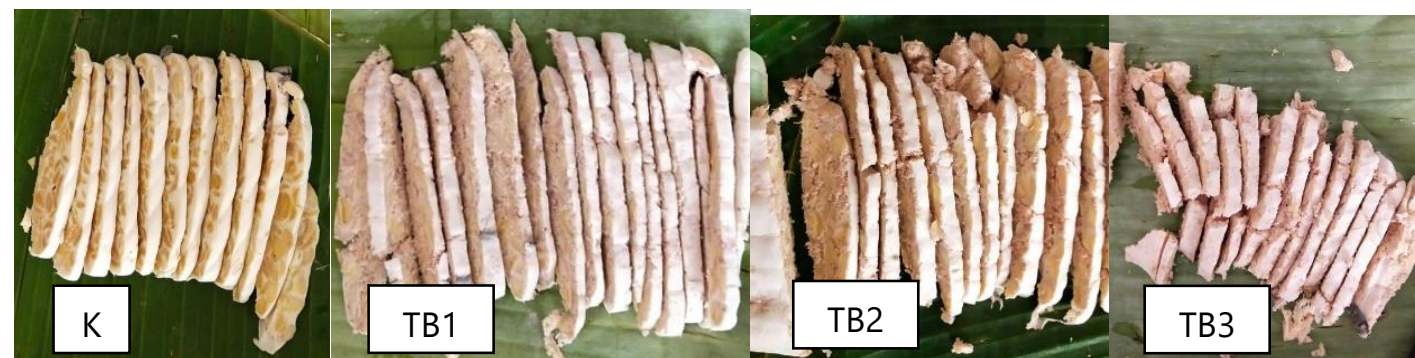

Gambar 2. Perbandingan tekstur tempe. Kontrol: 100\% kedelai; TB1: 70\% kedelai; TB2: 60\% kedelai; TB3: $50 \%$ kedelai

Tabel 1. Hasil Uji Proksimat Tempe Bonggol Kitosan

\begin{tabular}{lcccccc}
\hline \multirow{2}{*}{ Perlakuan } & \multicolumn{5}{c}{ Uji Proksimat } \\
& Kadar air (\%) & Kadar abu (\%) & Protein (\%) & Lemak (\%) & KH (\%) & Serat Kasar (\%) \\
\hline Kontrol & $59,85^{\mathrm{a}}$ & $1,24^{\mathrm{a}}$ & $19,25^{\mathrm{a}}$ & $5,96^{\mathrm{a}}$ & $13,7^{\mathrm{a}}$ & $1,42^{\mathrm{a}}$ \\
TB1 & $68,53^{\mathrm{b}}$ & $1,18^{\mathrm{a}}$ & $17,35^{\mathrm{b}}$ & $5,48^{\mathrm{ab}}$ & $7,44^{\mathrm{b}}$ & $1,59^{\mathrm{ab}}$ \\
TB2 & $71,27^{\mathrm{b}}$ & $1,01^{\mathrm{a}}$ & $17,13^{\mathrm{b}}$ & $4,96^{\mathrm{ab}}$ & $5,60^{\mathrm{b}}$ & $1,78^{\mathrm{ab}}$ \\
TB3 & $68,61^{\mathrm{b}}$ & $1,19^{\mathrm{a}}$ & $15,14^{\mathrm{c}}$ & $4,01^{\mathrm{bc}}$ & $11,03^{\mathrm{a}}$ & $2,05^{\mathrm{bc}}$ \\
\hline
\end{tabular}

Keterangan: notasi huruf yang berbeda menunjukkan berbeda nyata $(p<0.05)$

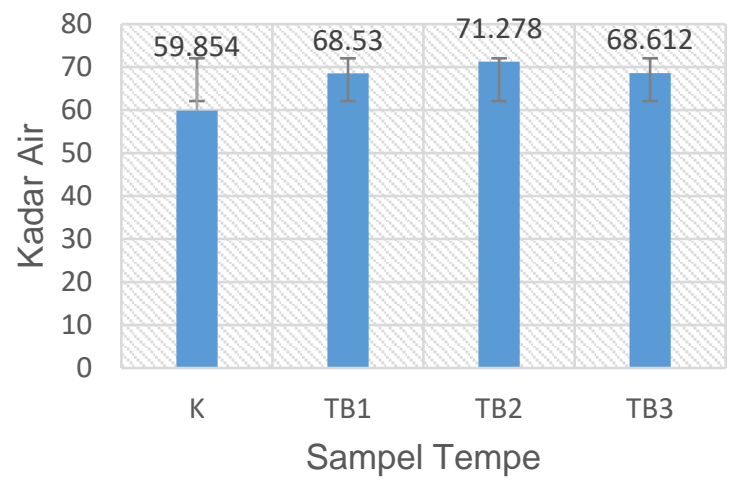

Gambar 3. Grafik Kadar Air Tempe Substitusi Bonggol (30\%; 40\%; 50\%) dan Perendaman Kitosan $2 \%$

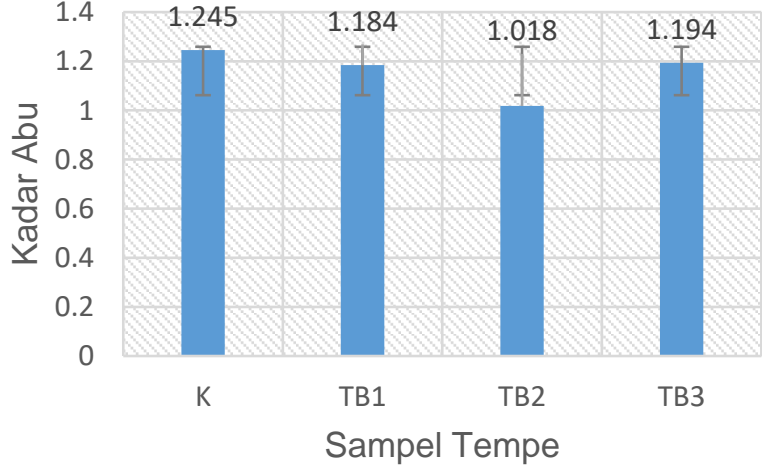

Gambar 4. Grafik Kadar Abu Tempe Substitusi Bonggol (30\%; 40\%; 50\%) dan Perendaman Kitosan 2\% 


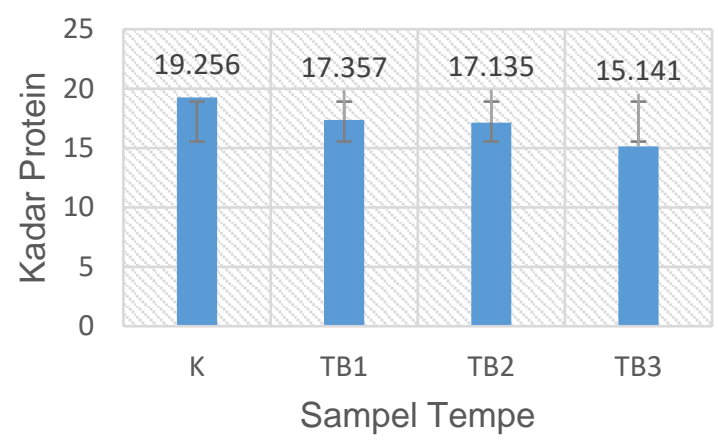

Gambar 5. Grafik Kadar Protein Tempe Substitusi Bonggol (30\%; 40\%; $50 \%$ ) dan Perendaman Kitosan 2\%

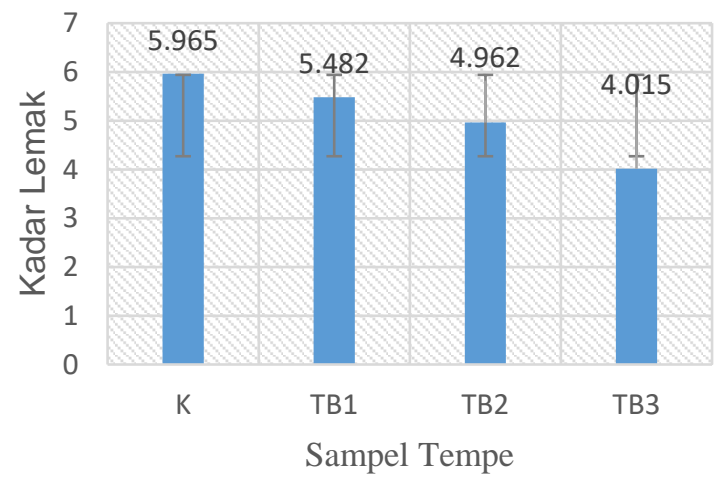

Gambar 6. Grafik Kadar Lemak Tempe Substitusi Bonggol (30\%; 40\%; $50 \%$ ) dan Perendaman Kitosan 2\%

menunjukkan perbedaan yang signifikan $(p>0,05)$. Hal ini menjelaskan dengan penggantian kedelai dengan bonggol tidak memberikan pengaruh terhadap perbedaan kandungan abu. Kandungan abu berkaitan dengan kandungan total mineral pada kedelai dan bonggol pisang. Hal ini juga terjadi tempe kacang hijau yang memiliki hasil kadar abu cukup baik yaitu 1,28\% (Maryam, 2015). Kadar abu tempe bonggol pisang memenuhi standar tempe kedelai SNI 3144:2009 dengan nilai maksimal 1,5\%.

\section{Kadar Protein}

Pada Gambar 5, dapat dilihat grafik perbedaan kandungan protein yang menurun. Hasil analisis diperoleh perbedaan yang signifikan antara kandungan tempe bonggol kitosan dengan kontrol $(p<0,05)$. Substitusi kedelai dengan bonggol memberikan pengaruh terhadap perubahan kandungan protein.

Penurunan kandungan protein disebabkan substitusi kedelai dengan bonggol yang semakin meningkat jumlahnya menyebabkan protein yang berasal dari kedelai berkurang. Sebab ada interaksi antara bakteri flora normal dengan kapang yang mampu meningkatkan kadar protein kedelai. Enzim proteolitik dari kapang mampu mengurai protein menjadi asam amino sehingga akan meningkatkan nitrogen terlarut (Kusnandar et al., 2020). Bonggol pisang tidak memiliki kandungan protein yang tinggi dibandingkan dengan kedelai. Setiap 100 gram bonggol basah maupun kering diketahui mengandung protein masing-masing sebesar 0,36 dan $3,40 \mathrm{~g}$ (Elisabeth, 2013). Tempe bonggol pisang ketiganya masih masuk standar minimal protein SNI 3114:2015 yaitu 15\%.

\section{Kadar Lemak}

Pada Gambar 6. dapat dilihat penurunan kandungan lemak pada tempe bonggol kitosan jika dibandingkan dengan kontrol.

Pada tempe yang disubstitusi dengan bonggol $50 \%$ yang sebelumnya direndam dalam larutan kitosan $2 \%$, menunjukkan pengaruh yang signifikan $(p<0,05)$ terhadap kandungan lemak. Bonggol pisang tidak mengandung lemak sedangkan kedelai dengan lemak $16,7 \mathrm{gr}$ mengalami penurunan setelah menjadi tempe yaitu $8,8 \mathrm{~g}$ lemak per 100 gram tempe. Hal ini sudah pasti akan mengurangi kandungan lemak yang berasal dari kedelai. Berbeda dengan tempe bekatul hasil penelitian Cempaka et al., (2018), menemukan bahwa campuran bekatul dan pemberian $2 \%$ kitosan tidak mempengaruhi kandungan lemak. Pada penelitian ini sama dengan perlakuan substitusi $30 \%$ dan $40 \%$ bonggol pisang tidak berpengaruh nyata ( $p>0,05)$ terhadap perubahan lemak bila dibandingkan dengan kontrol. Tempe bonggol pisang tidak memenuhi SNI 3114:2015 karena dibawah 7 sebagai syarat minimal. 


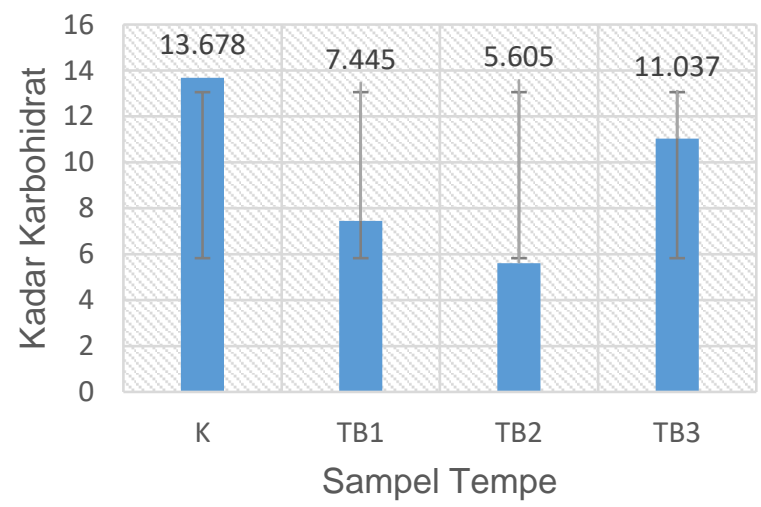

Gambar 7. Grafik Kadar Karbohidrat Tempe Substitusi Bonggol (30\%; 40\%; $50 \%$ ) dan Perendaman Kitosan $2 \%$

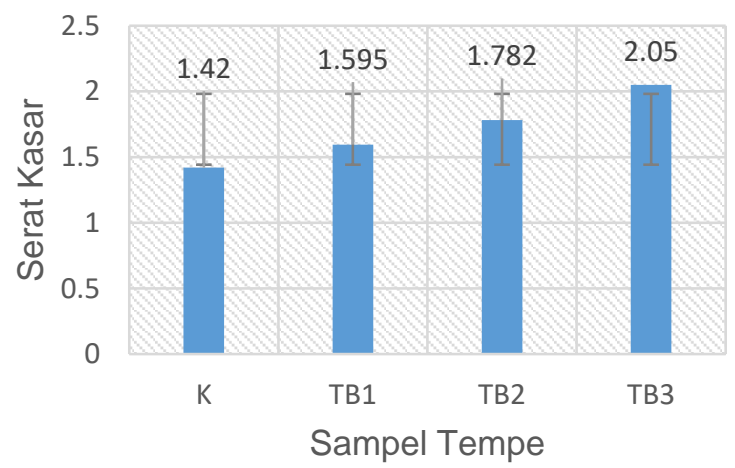

Gambar 8. Grafik Kandungan Serat Kasar Tempe Substitusi Bonggol (30\%; $40 \%$; 50\%) dan Perendaman Kitosan $2 \%$

\section{Kadar Karbohidrat}

Pada Gambar 7., terjadi penurunan kandungan karbohidrat pada tempe dengan substitusi $30 \%$ dan $40 \%$ bonggol pisang. Sedangkan kadar karbohidrat meningkat kembali pada substitusi bonggol pisang sebanyak $50 \%$. Setelah dilakukan analisis LSD, pemberian $50 \%$ bonggol sebagai pengganti kedelai tidak memengaruhi kandungan karbohidrat dibandingkan dengan kontrol $(p>0,05)$. Hal ini dapat dijelaskan karena bonggol pisang mengandung serat pangan yang termasuk komponen karbohidrat. Kandungan karbohidrat pada bonggol pisang sebesar
66,20 gr/100 gr dalam keadaan kering (Elisabeth, 2013). Meskipun pada formula TB1 dan TB2 kadar karbohidrat lebih rendah dan berbeda nyata $(p<0,05)$ dibandingkan dengan kontrol. Karena substitusi jumlah bonggol pisang yang ditambahkan tidak mencukupi menggantikan karbohidrat dari kedelai. Terlebih lagi kadar karbohidrat kedelai apabila menjadi tempe akan turun menjadi 13,5 gr/100 gr (Roni, 2013). Substitusi kedelai dengan bonggol pisang tidak mempengaruhi proses fermentasi karena bonggol mengandung karbohidrat. Fermentasi tempe akan terjadi apabila bahan tempe mengandung protein dan karbohidrat (Asngad et al., 2011).

\section{Kadar Serat Kasar}

Pada Gambar 8. terjadi peningkatan kandungan serat kasar. Kandungan serat tertinggi pada formula TB3. Hal ini dapat dijelaskan bahwa kadar serat semakin meningkat disebabkan substitusi bonggol yang dinaikkan dari 30\% menjadi 50\%. Hasil penelitian Komalawati dkk. (2016), bonggol pisang segar dari berbagai jenis pisang memiliki kadar serat 4-7\%. Sedangkan Saragih (2018), menemukan serat bonggol pisang kapok memiliki kadar serat 29,62\% sehingga mampu meningkatkan kadar serat dalam brownies. Kadar serat dipengaruhi juga dari pertumbuhan hifa dari Rhizopus sp., dinding sel hifa diketahui tersusun dari kitin dan selulosa (Widoyo et al., 2015). Penelitian Sudaryantiningsih dan Yonathan (2017) menambahkan pare sebagai sumber serat pada tempe diketahui meningkatkan kadar serat. Sedangkan penelitian Pilco et al. (2019), membuat inovasi pembuatan tempe dengan campuran antara kacang buncis dan quinoa yang kaya serat sebagai penambah serat. Kadar serat pada tempe bonggol pisang masih memenuhi standar SNI 3114:2015 dengan nilai maksimal 2,5\%.

\section{pH (Derajat Keasaman)}

Pada Gambar 9. menunjukkan diagram nilai $\mathrm{pH}$ yang menurun pada substitusi kedelai dengan bonggol pisang dan perendalam dalam larutan kitosan $2 \%$. 
Tabel 2. Hasil Pengamatan Visual Karakteristik Tempe Bonggol Pisang Kitosan

\begin{tabular}{|c|c|c|c|c|c|c|c|c|}
\hline \multirow[t]{2}{*}{ Suhu } & \multirow[t]{2}{*}{ Perlakuan } & \multirow{2}{*}{$\begin{array}{c}\text { Perubahan } \\
\text { Karakteristik }\end{array}$} & \multicolumn{6}{|c|}{ Hasil Pengamatan Masa Simpan } \\
\hline & & & Hari-2 & Hari-3 & Hari-4 & Hari-5 & Hari-6 & Hari-7 \\
\hline \multirow{16}{*}{$27-29^{\circ} \mathrm{C}$} & \multirow{6}{*}{ Warna } & Kontrol & Putih & Putih & Putih & Kecoklatan & Coklat & Coklat \\
\hline & & TB1 & Putih & Putih & Putih & Putih & $\begin{array}{l}\text { Putih } \\
\text { kecoklatan }\end{array}$ & Coklat \\
\hline & & TB2 & Putih & Putih & Putih & $\begin{array}{l}\text { Putih } \\
\text { kecoklatan }\end{array}$ & $\begin{array}{l}\text { Putih } \\
\text { kecoklatan }\end{array}$ & Coklat \\
\hline & & TB3 & Putih & Putih & $\begin{array}{l}\text { Putih } \\
\text { ada } \\
\text { bagian } \\
\text { kuning }\end{array}$ & $\begin{array}{l}\text { Putih ada } \\
\text { bagian } \\
\text { kuning }\end{array}$ & $\begin{array}{l}\text { Putih } \\
\text { kecoklatan }\end{array}$ & $\begin{array}{l}\text { Putih } \\
\text { kecoklatan }\end{array}$ \\
\hline & & Kontrol & $\begin{array}{l}\text { Khas } \\
\text { tempe }\end{array}$ & $\begin{array}{l}\text { Khas } \\
\text { tempe }\end{array}$ & $\begin{array}{l}\text { Khas } \\
\text { tempe }\end{array}$ & $\begin{array}{l}\text { Berbau } \\
\text { amoniak }\end{array}$ & $\begin{array}{l}\text { Berbau } \\
\text { amoniak }\end{array}$ & $\begin{array}{l}\text { Berbau } \\
\text { amoniak }\end{array}$ \\
\hline & & TB1 & $\begin{array}{l}\text { Khas } \\
\text { tempe }\end{array}$ & $\begin{array}{l}\text { Khas } \\
\text { tempe }\end{array}$ & $\begin{array}{l}\text { Khas } \\
\text { tempe }\end{array}$ & Khas tempe & $\begin{array}{l}\text { Berbau } \\
\text { amoniak }\end{array}$ & $\begin{array}{l}\text { Berbau } \\
\text { amoniak }\end{array}$ \\
\hline & \multirow[t]{3}{*}{ Aroma } & TB2 & $\begin{array}{l}\text { Khas } \\
\text { tempe }\end{array}$ & $\begin{array}{l}\text { Khas } \\
\text { tempe }\end{array}$ & $\begin{array}{l}\text { Khas } \\
\text { tempe }\end{array}$ & $\begin{array}{l}\text { Berbau } \\
\text { sedikit } \\
\text { amoniak }\end{array}$ & $\begin{array}{l}\text { Berbau } \\
\text { amoniak }\end{array}$ & $\begin{array}{l}\text { Berbau } \\
\text { amoniak }\end{array}$ \\
\hline & & TB3 & $\begin{array}{l}\text { Khas } \\
\text { tempe }\end{array}$ & $\begin{array}{l}\text { Khas } \\
\text { tempe }\end{array}$ & $\begin{array}{l}\text { Khas } \\
\text { tempe }\end{array}$ & Khas tempe & $\begin{array}{l}\text { Berbau } \\
\text { sedikit } \\
\text { amoniak }\end{array}$ & $\begin{array}{l}\text { Berbau } \\
\text { sedikit } \\
\text { amoniak }\end{array}$ \\
\hline & & Kontrol & $\begin{array}{l}\text { Agak } \\
\text { padat }\end{array}$ & Padat & Padat & $\begin{array}{l}\text { Basah agak } \\
\text { lembek }\end{array}$ & $\begin{array}{l}\text { Lembek } \\
\text { dan benyek }\end{array}$ & $\begin{array}{l}\text { Lembek } \\
\text { dan benyek }\end{array}$ \\
\hline & \multirow[t]{4}{*}{ Tekstur } & TB1 & $\begin{array}{l}\text { Agak } \\
\text { padat }\end{array}$ & Padat & Padat & Padat & $\begin{array}{l}\text { Padat agak } \\
\text { lembek }\end{array}$ & $\begin{array}{l}\text { Padat agak } \\
\text { lembek }\end{array}$ \\
\hline & & TB2 & $\begin{array}{l}\text { Agak } \\
\text { rapuh }\end{array}$ & Padat & Padat & Padat & $\begin{array}{l}\text { Padat agak } \\
\text { lembek }\end{array}$ & $\begin{array}{l}\text { Padat agak } \\
\text { lembek }\end{array}$ \\
\hline & & TB3 & Rapuh & Padat & Padat & Padat & $\begin{array}{l}\text { Padat agak } \\
\text { lembek }\end{array}$ & $\begin{array}{l}\text { Padat agak } \\
\text { lembek }\end{array}$ \\
\hline & & Kontrol & Kompak & Kompak & Kompak & $\begin{array}{l}\text { Agak } \\
\text { kompak }\end{array}$ & $\begin{array}{l}\text { Tidak } \\
\text { Kompak }\end{array}$ & $\begin{array}{l}\text { Tidak } \\
\text { Kompak }\end{array}$ \\
\hline & \multirow[t]{3}{*}{ Kekompakan } & TB1 & Kompak & Kompak & Kompak & Kompak & $\begin{array}{l}\text { Agak } \\
\text { kompak }\end{array}$ & $\begin{array}{l}\text { Agak } \\
\text { kompak }\end{array}$ \\
\hline & & TB2 & Kompak & Kompak & Kompak & Kompak & $\begin{array}{l}\text { Agak } \\
\text { kompak }\end{array}$ & $\begin{array}{l}\text { Agak } \\
\text { kompak }\end{array}$ \\
\hline & & TB3 & Kompak & Kompak & Kompak & Kompak & $\begin{array}{l}\text { Agak } \\
\text { kompak }\end{array}$ & $\begin{array}{l}\text { Agak } \\
\text { kompak }\end{array}$ \\
\hline
\end{tabular}

Penurunan nilai $\mathrm{pH}$ dapat disebabkan karena perendaman dalam larutan kitosan $2 \%$ yang bersifat asam. Hal ini disebabkan kitosan dilarutkan dalam larutan asam seperti asam asetat 10\%, asam piruvat $10 \%$ dan asam sitrat $10 \%$ (Goni et al., 2017). Pada penelitian penambahan kitosan pada pengawetan tahu dan sirup nanas dilaporkan terjadi penurunan $\mathrm{pH}$ yang berkaitan dengan sedikitnya jumlah bakteri yang mampu berkembang biak (Nurazizah, 2014; Cahyono et al., 2018). Penurunan nilai $\mathrm{pH}$ mempengaruhi kadar protein yang juga menjadi rendah karena terjadi denaturasi protein (Sonja, 2014). Tingkat keasaman dapat mempersingkat waktu fermentasi tempe (Mubarok et al., 2019) yang kedelainya direndam dalam asam sitrat. Tempe hasil penelitian Roni (2013) memanfaatkan kulit dan bonggol nanas untuk meningkatkan suasana asam. Pertumbuhan hifa Rhizopus sp. lebih cepat bertumbuh dalam suasana asam, oleh karena itu keasaman tempe mempengaruhi tingkat keberhasilan pembuatan tempe. Kondisi asam juga mampu menghambat perkembangan mikroba yang merugikan (Ramdani et al., 2017). Perendaman kedelai 


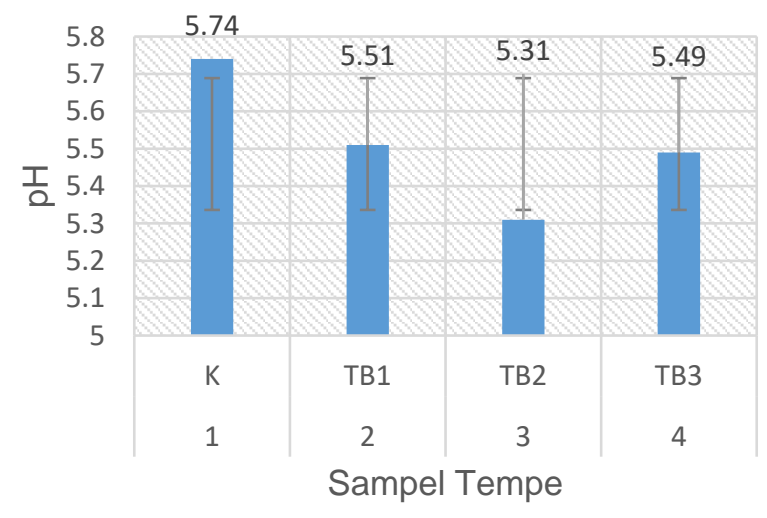

Gambar 9. Grafik Nilai pH Tempe Substitusi Bonggol (30\%; 40\%; 50\%) dan Perendaman Kitosan $2 \%$

dan bonggol pisang dalam larutan kitosan $2 \%$ mampu meningkatkan suasana asam dan meningkatkan proses fermentasi tempe bonggol pisang. Rhizopus mampu tumbuh mengikat kuat butiran bonggol dan kedelai.

\section{Daya simpan}

Pengamatan secara visual terhadap daya simpan tempe bonggol pisang kitosan yang disimpan dalam suhu ruang $23^{\circ}-29^{\circ} \mathrm{C}$. Pada hari ke-3 tempe dengan pembungkus daun pisang menunjukkan masih terlihat pertumbuhan miselium kapang Rhizopus sp. Pengamatan dilanjutkan hingga pada hari ke-6, hasil visual dapat dilihat pada Tabel 2.

Pada Tabel 2. di atas tempe yang disubstitusi dengan bonggol yang semakin meningkat, pertumbuhan miselia lebih lambat pada hari ke-3, dibandingkan kontrol. Tetapi pada hari ke-4 miselia sudah tampak menutupi tempe bonggol sama dengan kontrol. Keempat sampel berbau khas tempe hingga hari ke-4. Pada hari ke-6 menunjukkan mulai bau amoniak pada kontrol dan substitusi $40 \%$ bonggol. Sedangkan tempe bonggol substitusi 30\% dan $50 \%$ masih berbau khas tempe. Tekstur keempat sampel sampai hari ke-5 masih padat. Pada hari ke- 6 kontrol sudah menjadi lembek dan basah. Kekompakan hingga hari ke-6 masih kompak.

Hasil pengamatan umur simpan tempe bonggol kitosan dengan pembungkus daun pisang dibandingkan dengan kontrol. Pertumbuhan miselia yang lambat pada substitusi bonggol pisang dapat disebabkan luas permukaan bonggol yang diparut lebih padat dan sempit dibandingkan kedelai. Sehingga miselia membutuhkan waktu untuk berikatan di media bonggol pisang. Pertumbuhan miselia yang mengikat bonggol pisang diantara kedelai semakin erat sebanding dengan banyaknya substitusi yang ditambahkan. Tekstur tempe bonggol pisang pada penelitian ini mirip dengan tempe kacang merah dan bekatul yang memerlukan waktu fermentasi lebih lama untuk pertumbuhan miselia yang menutupi keseluruhan permukaan. Jalinan miselia yang erat membuat tekstur tempe menjadi kompak dan padat (Asngad et al., 2011). Kekompakan pada tempe bonggol pisang disebabkan antioksidan dalam daun pisang menghambat pertumbuhan bakteria lain sehingga membuat miselia kapang dapat bertumbuh dengan subur (Putri et al., 2018).

Tekstur tempe yang semakin padat disebabkan karena tempe ditaruh dalam suhu ruang. Suhu yang tinggi dapat meningkatkan laju respirasi yang mempengaruhi kadar air tempe. Hal ini dibuktikan dengan penelitian Purwanto dan Weliana (2018), dimana tempe akan menjadi keras ketika disimpan pada suhu $15^{\circ} \mathrm{C}$ dibanding suhu lebih rendah $5^{\circ} \mathrm{C}$. Kitosan memiliki kemampuan menyerap air, saat kedelai dan bonggol direndam dalam kitosan, terjadi pengurangan kadar air. Masa simpan tempe dalam suhu ruang dapat bertahan 1-2 hari dalam suhu ruang 25$30^{\circ} \mathrm{C}$. Pembusukan dapat disebabkan faktor pembungkusan, suhu dan kadar air. Indikator kebusukan tempe dapat dilihat dari perubahan warna, bau, rasa, dan tekstur. Pada tempe bonggol kitosan tempe mengalami perubahan secara visual pada hari ke-7 sedangkan tempe kedelai sudah memperlihatkan perubahan karakteristik warna, bau, tekstur dan kekompakan pada hari ke-5 (Umami et al., 2018). 


\section{KESIMPULAN}

Substitusi bonggol pisang dan perendaman kitosan pada pembuatan tempe kedelai memberikan pengaruh terhadap kandungan proksimat, $\mathrm{pH}$, kadar air dan serat kasar. Penurunan kandungan lemak dan protein masih memenuhi standar SNI 3414:2015. Terjadi peningkatan kandungan air yang tidak memenuhi standar SNI tempe. Derajat keasaman $(\mathrm{pH})$ makin menurun sangat baik untuk mempercepat proses fermentasi pertumbuhan Rhizopus sp. Serat kasar dalam tempe bonggol semakin meningkat sejalan dengan prosentase substitusi bonggol pisang. Kandungan serat tertinggi diperoleh pada substitusi bonggol pisang $50 \%$ dan masih memenuhi standar SNI tempe. Tekstur dan aroma tempe dengan substitusi bonggol pisang sesuai dengan standar SNI tempe berwarna putih, kompak dan berbau khas tempe.

\section{UCAPAN TERIMA KASIH}

Ucapan terima kasih disampaikan peneliti kepada Lembaga Penelitian dan Pengabdian Masyarakat, Universitas Dhyana Pura Bali yang telah mendanai kegiatan ini melalui Hibah Penelitian Pemula Tahun Anggaran 2020.

\section{DAFTAR PUSTAKA}

Astuti, R., Siti A., \& Agustin, S. (2014). Komposisi Zat Gizi Tempe Yang Difortifikasi Zat Besi dan Vitamin A Pada Tempe Mentah dan Matang. AGRITECH, 34(2), 151-159.

Asngad, A., Suparti, \& Priyonggo, BL. (2011). Uji kadar serat, karbohidrat, dan sifat organoleptik pada pembuatan tempe dari bahan dasar kacang merah (Vigna umbellate) dengan penambahan bekatul. Jurnal Penelitian Sains \& Teknologi, 12(1), 23 $-36$.

Bailey, RL., Keith, PWJ., \& Robert, EB. (2015). The Epidemiology of Global Micronutrient Deficiencies. Ann Nutr Metab, 66(2), 22-33.

Cahyono, E., Stevy IMW., \& Nurfaida K. (2018). Aplikasi Kitosan Kulit Udang
Windu (Panaeus monodon) Sebagai Pengawet Alami Pada Tahu. Jurnal IImiah Tindalung, 4(1), 41-44.

Cempaka, L., Naila, E., Ardiansyah, Dody, DH., \& Rizki, MA. (2018). Proximate Composition, Total Phenolic Content, and Sensory Analysis of Rice Bran Tempeh. Makara Journal of Science, 22(2), 89-94.

Cruz-Requena, M., Cristóbal, NAG., Lilia, APB., María, GCC., Maria, TSC., Juan, CCE., \& Raul, RH. (2016). Dietary fiber: An ingredient against obesity. Emirates Journal of Food and Agriculture, 28(8): 522-530.

Dewayani, W., dan Andi, D. (2016). Karakteristik Fisikokimia Beberapa Varietas Kedelai dan Pengolahannya Menjadi Tempe. Banjarbaru: Prosiding Seminar Nasional Inovasi Teknologi Pertanian.

Dewi, IWR., Chorul, A., \& Esti, W. (2014). Karakteristik sensoris, nilai gizi dan aktivitas antioksidan tempe kacang gude (Cajanus cajan) dan tempe kacang tunggak (Vigna unguiculata) dengan berbagai variasi waktu fermentasi. Biofarmasi, 12(2), 73-82.

Dianto, K., Vonny, SJ., \& Rahmayuni. (2018). Penilaian Sensori Flakes Tepung Bonggol Pisang Dengan Penambahan Tepung Tempe. Jurnal Online Mahasiswa Faperta, 5(1), 1-9.

Elisabeth, DAA. (2013). Kerupuk Bonggol Pisang: Dari Limbah Yang Kaya Gizi Ke Meja Makan Kita. Sinar Tani Agroinovasi Badan Litbang Pertanian Edisi 24-30, No.3504 Tahun XLIII.

Goni, MG., Barbara, T., Sara, IR., and Maria, RM. (2017). Lactic acid as potential substitute of acetic acid for dissolution of chitosan: preharvest application to Butterhead lettuce. Journal Food Science Technology, 54(3), 620-626.

Hapsari, NI., dan Iwan, R. (2017). FaktorFaktor yang Mempengaruhi Kerawanan dan Ketahanan Pangan dan Implikasi Kebijakannya di Kabupaten Rembang. Jurnal Wilayah dan Lingkungan, 5(2), 125-140. 
Hasti, AS., Anis, A., Desy, H., Estuningsih, Heni, NK., \& Dwi, SH. (2014). The Fortification Tempeh of Rice Bran Chitosan as Functional Food Antihypercholesterolemia in Indonesia. International Journal of Bioscience, Biochemistry and Bioinformatics, 4(5), 423-427.

Hu, Z., dan Michael GG. (2018). Challenges and opportunities related to the use of chitosan as a food preservative. Journal of Applied Microbiology, 126(5), 1318-1331.

Isbandi dan Rusdiana, S. (2014). Strategi Tercapainya Ketahanan Pangan Dalam Ketersediaan Pangan Di Tingkat Regional. Agriekonomika, 3(2), 117-132.

Jumiati dan Fitriana, F. (2018). Pemanfaatan Jantung Pisang Dan Kluwih Pada Pembuatan Abon Ikan Tongkol (Euthynnus Affinis) Ditinjau Dari Analisis Proksimat, dan Uji Asam Tiobarbiturat (TBA). REKA PANGAN, 12(1), 60-66.

Komalasari, NT., Suter K., dan Darmayanti, LPT. (2016). Kajian Karakteristik Lawar Bonggol Pisang (Musa Sp). Jurnal Ilmu dan Teknologi Pangan, 5(1), 1-10.

Krismaputri, ME., Hintono, A., \& Pramono, YB. (2013). Kadar Vitamin A, Zat Besi (Fe) dan Tingkat Kesukaan Nugget Ayam yang Disubstitusi Dengan Hati Ayam Broiler. Animal Agriculture Journal, 2(1), 288 - 294.

Kurniawan, ND., Bhakti. ES. \& Bambang, D. (2019). Kadar Lemak, Kadar Air, Kadar Protein, Dan Antioksidan Tempe Edamame (Glycine max (L) Merrill) Dengan Jenis Pengemas Yang Berbeda. Jurnal Teknologi Pangan, 3(2), 355-360.

Kusnandar, F., Vega, WK., Antung SF., \& Eko, HP. (2020). Perubahan Komposisi Kimia Tempe Kacang Merah (Phaseolus vulgaris L.) Selama Pengolahan. Jurnal Teknologi Pangan, 14(1), 108-123.
Lestari, DAA., Drajat, M., \& Ikeu, T. (2018). Pengembangan Indeks Ketahanan Pangan Dan Gizi Tingkat Kabupaten Di Kabupaten Bandung Barat. Jurnal Ekonomi Pertanian dan Agribisnis, 2(1), 62-76.

Lestari, OA., dan Eva, M. (2016). Pengaruh Fermentasi Tempe Jagung Terhadap Kandungan Protein dan Karotenoid. Jurnal Teknologi Pertanian, 17(2), 149-154.

Maryam, S. (2015). Komponen Gizi Tempe Kacang Hijau (Vigna Radiata L) Hasil Proses Fermentasi Menggunakan Inokulum Serbuk. Seminar Nasional Riset Inovatif III.

Morachis-Valdes, AG., Leobardo, MGO., Imelda, GA., Maria, DHN., Daniel, DB., and Octavio, DG. (2017). Effect of Chitosan Edible Coating on The Biochemical and Physical Characteristics of Carp Fillet (Cyprinus carpio) Stored at $-18^{\circ} \mathrm{C}$. International Journal of Food Science, 2017(2812483), 1-10.

Mubarok, ZR., Mohammad, F., \& Deden. (2018). Pemanfaatan Jantung Pisang Dan Kluwih Pada Pembuatan Abon Ikan Tongkol (Euthynnus Affinis) Ditinjau Dari Analisis Proksimat, dan Uji Asam Tiobarbiturat (TBA). Jurnal Ilmiah Teknik Kimia UNPAM, 12(1), 60-66.

Muthmainna, Sri, MS., \& Supriadi. (2016). Pengaruh Waktu Fermentasi Terhadap Kadar Protein dari Tempe Biji Buah Lamtoro Gung (Leucaena leucocephala). J. Akad. Kim., 5(1), 5054.

Novitriani, K., dan Dina, S. (2014). Analisa Kadar lodium Pada Telur Asin. Jurnal Kesehatan Bakti Tunas Husada, 12(1), 236-241.

Nurazizah. (2014). Penggunaan Kitosan Sebagai Bahan Pengawet pada Sirup Nanas. Jurnal Online Mahasiswa, 1(1), 1-15.

Pilco, CJ., Darwin, NT., Riveliño, R., Nancy, JG., Katherin, BM., Nelson, M., Byron, H., Marx, IG., \& Favian, BM. (2019). 
Analysis of protein, fiber content and amino acid profiles in Tempeh obtained by fermentation of beans (Phaseolus vulgaris L.) and quinoa (Chenopodium quinoa) with Rhizopus oligosporus. Eurasia J Biosci, 13(2), 1195-1199.

Putri, BD., Sri, W., \& Wiharyani, W. (2018). Tempe Kacang Komak Dengan Beberapa Pembungkus Yang Berbeda Selama Fermentasi. Pro Food (Jurnal Ilmu dan Teknologi Pangan), 4(2), 343350.

Rakhmawati. (2019). Pemanfaatan Bonggol Pisang Menjadi Stick Nugget Untuk Peningkatan Gizi Masyarakat Desa Soket Laok Tragah Kabupaten Bangkalan. Jurnal IImiah Pangabdhi, 5(1), 44-51.

Ramdani, N., Reni, S., \& Lalu, KA. (2017). Daya Terima Konsumen dan Kandungan Gizi Tempe Kacang Tunggak Rumput Laut. Jurnal Gizi Prima, 2(2), 94-103.

Raswanti, H., Ary, OA., Sarah, ROA., Aldiano, A., \& In-in, H. (2018). Upaya Peningkatan Konsumsi Tempe Melalui Diversifikasi Olahan. AGRICORE: Jurnal Agribisnis dan Sosial Ekonomi Pertanian, 3(1), 359-426.

Razie, F., dan Lina, W. (2018). Kombinasi Pengemasan Vakum Dan Ketebalan Kemasan Untuk Memperpanjang Umur Simpan Tempe. AGRITEPA, 4(2), 94-107.

Rohmani, S., dan Adi, Y. (2019). Pemberdayaan Masyarakat melalui Wirausaha Kerupuk Bonggol Pisang di Kabupaten Sukoharjo. Agrokreatif Jurnal Ilmiah Pengabdian kepada Masyarakat, 5(2), 103-108.

Roni, A. (2013). Pengaruh Penambahan Cairan Kulit Dan Bonggol Nanas Pada Proses Pembuatan Tempe. Berkala Teknik, 3(2), 573-585.

Rosariastuti, R., Sumani, \& Aktavia, H. (2018). Pemanfaatan Batang Pisang Untuk Aneka Produk Makanan Olahan Di Kecamatan Jenawi, Karanganyar. Journal of Community Empowering a Services, 2(1), 21-29.
Ruhee, RT., dan Katsuhiko, S. (2018). Dietary fiber and its effect on obesity: A review article. Advances In Medical Research 1(1), 3-15.

Schmidhuber, J., Patrick, S., Kairsten, .F, Bethany, H., Joseph, S., Alexander, L., Leslie, C,, Masako, H., Christopher, M., \& Ashkan, A. (2018). The Global Nutrient Database: availability of macronutrients and micronutrients in 195 countries from 1980 to 2013. The Lacent Healthy Longevity, 2(8), 353368.

Saragih, B., dan Katarida, D. (2018). Pemanfaatan Tepung Bonggol Pisang (Musa Paradisiaca Linn) Sebagai Pangan Alternatif Dalam Mendukung Ketahanan Pangan. Jurnal TIBBS Teknologi Industri Boga dan Busana, 9(1), 22-29.

Suharyanto H. (2011). Ketahanan Pangan. Jurnal Sosial Humaniora, 4(2), 186194.

Sudaryantiningsih, C., dan Yonathan, SP. (2017). Upaya Peningkatan Serat Tempe Kedele Melalui Penambahan Buah Pare (Momordica charantina) sebagai Pangan Fungsional. Jurnal Kesehatan Kusuma Husada, 8(1), 5761.

Supraptiningsih. (2012). Pengaruh Serbuk Serat Batang Pisang Sebagai Filler Terhadap Sifat Mekanis Komposit PVC-CaC) 3 . Yogyakarta: Majalah Kulit, Karet dan Plastik.

Sonja, VTL., dan Ima, N. (2014). Pengaruh Perendaman Biji Kedelai (Glycine Max, L. Merr) Dalam Media Perasan Kulit Nanas (Ananas Comosus (Linn.) Merrill) Terhadap Kadar Protein Pada Pembuatan Tempe. Jurnal Edubio Tropika, 2(2), 187-250.

Sari, KP., Jamaluddin, P., \& Andi, S. (2016). Fortifikasi Tempe Berbahan Dasar Kedelai Dan Biji Nangka. Jurnal Pendidikan Teknologi Pertanian, 2(1), 16-26.

Sine, Y., dan Endang, SS. (2016). Kandungan Asam Amino Pada Tempe Gude (Cajanus cajan (L.) Millps.). Prosiding Symbion (Symposium on 
Biology Education). p-ISSN: 2540752x e-ISSN: 2528-5726.

Sulistiyono, P., Samuel, \& Mey Mey, M. (2016). Pengaruh Pembungkus Tempe Terhadap Daya Simpan Dan Sifat Fisik Tempe. Buletin Media Informasi, 12(1), 1-5.

Vega, C., Daniel, E., Oktavia, P., Rikky, L., \& Sapto, A. (2013). Rekayasa Chitosan Sebagai Pengawet dan Meningkatkan Kadar Protein Dalam Tahu. Jurnal Ilmiah Perikanan Dan Kelautan, 5(2), 145-149.

Wardani, AS. (2018). Determinan Ketahanan Pangan Dan Gizi Rumah Tangga Petani Indonesia Di Kawasan Pedesaan. Jurnal Ekonomi, 1-14.

World Health Organization. (2017). Preventing and controlling micronutrient deficiencies in populations affected by an emergency. Nutrition for Health and Development
(NHD). WHO home page: http://www.who.int/.

Widoyo, S., Sri, H., \& Nandariyah. (2015). Pengaruh Lama Fermentasi Terhadap Kadar Serat Kasar dan Aktivitas Antioksidan Tempe Beberapa Varietas Kedelai. Biofarmasi, 13(2), 59-65.

Xing, Y., Qinglian, X., Xingchen, L., Chunkun, C., Li, M., Shaohua, L., Zhenming, C., \& Hongbin, L. (2016). Chitosan Based Coating with Antimicrobal Agents: Preparation, Property, Mechanism, and Application Effectiveness on Fruits and Vegetables. International Journal of Polymer Science, 2016(4851730), 124.

Yazid EA., dan Badilatun UN. (2017). Kadar Protein Terlarut Pada Ampas Kedelai Dari Hasil Proses Pembuatan Tempe Dengan Penambahan Ekstrak Kasar Papain (Crude Papain). Journal of Ners Community, 8(1), 45-52. 